Documento de Trabajo 2008-03

Facultad de Ciencias Económicas y Empresariales

Universidad de Zaragoza

\title{
FACTORS INFLUENCING E-DISCLOSURE IN LOCAL PUBLIC ADMINISTRATIONS
}

\author{
Carlos Serrano-Cinca* \\ Departamento de Contabilidad y Finanzas \\ Universidad de Zaragoza, España \\ http://ciberconta.unizar.es/charles.htm \\ serrano@unizar.es \\ Mar Rueda-Tomás \\ Departamento de Contabilidad y Finanzas \\ Universidad de Zaragoza, España \\ mrueda@unizar.es \\ Pilar Portillo-Tarragona \\ Departamento de Contabilidad y Finanzas \\ Universidad de Zaragoza, España \\ portillo@unizar.es
}

\begin{abstract}
This paper studies the determinants of voluntary Internet financial reporting (edisclosure) by local public administrations. It presents hypotheses regarding the relationship between e-disclosure and city size, the issuing of municipal bonds, financial features, Internet visibility, the level of e-government and diverse political aspects. It also examines the influence of external factors, such as citizens' income level, their educational level and their socio-political commitment. The hypotheses were empirically tested, using a sample of 92 Spanish local public administrations. The data support the hypotheses, with different levels of robustness, and show that size, political will and citizens' income level all affect e-disclosure.
\end{abstract}

\section{KEY WORDS}

Local public administrations, Internet financial reporting, e-disclosure, egovernment

\footnotetext{
* Corresponding author. Gran Vía 2, 50005 Zaragoza, Spain. Telephone: +34 976762157. Fax number: +34976 761769. serrano@unizar.es
} 


\section{FACTORS INFLUENCING E-DISCLOSURE IN LOCAL PUBLIC ADMINISTRATIONS}

\section{INTRODUCTION}

By consulting the websites of companies listed on the Stock Exchange we can discover, in the majority of cases, how much their President earns, the allowances received by their directors and other data regarding their finances. Various countries have adopted legislative measures which require firms to disclose financial information via the Internet and which promote corporate governance codes. In the case of Spain, legislation requires firms which are quoted on the Stock Exchange to maintain a website which includes information for investors. By contrast, a quick glance at the websites of Spanish local public administrations reveals that many of them do not offer even minimal budgetary information, and certainly not the mayor's salary, paid for by citizens. Only in one of the approximately 100 town halls studied do we find complete financial and non-financial information, including councillors' earnings, a clear example of “Do as I say, not as I do". This has motivated us to undertake an analysis of the financial information available on local public administrations' websites and the circumstances which favour such disclosure.

There can be no doubt about the role played by technologies in the improvement of the organisation itself and its contribution to the increase in citizens' participation in political decision-making (Moon, 2002). Electronic democracy initiatives such as participatory budgets, electronic voting or information collection via forums and citizens' blogs permit greater popular participation in the democratic processes. The Internet offers the possibility of increasing interaction between citizens and the administration, which is what distinguishes it from the traditional public administration (Chadwick, 2003).

Recent legislative reforms encourage citizen participation in local public life. In the case of Europe, the European Committee of Ministers Recommendation 19/2001 established the basic principles of local democratic participation policies. This recommendation has stimulated the development of various national regulations. In the case of Spain, Law 57/2003 regarding Measures for the Modernisation of Local Government and Law 11/2007, which regulates Electronic Access by Citizens to Public 
Services, recommend governments to incorporate citizens' participation policies and establish the legal framework for local authorities to also adopt such policies.

From the empirical point of view, Katchanovski and La Porte (2005) analyse whether the level of democracy affects the openness of electronic governments, which in turn creates new possibilities for interaction between citizens and governments. The openness of electronic governments index employed in the study includes, among other factors, the information provided by the administration on its website. The analysis shows that the level of democracy affects the openness of electronic governments, creating new possibilities for citizen-administration interaction.

Wang and Rubin (2004, page 363) define e-government "as a way for the government to use internet technology and applications (e.g. the websites) to provide the public with more convenient access to government information”. Brown (2005, page 243) argues that "e-government creates vehicles for services to the public" and "also create a direct relationship between the citizen and state service providers”. The same study states that "it has only been with the development of e-government that the information assets of government have been understood to be as important as the financial and human resources that have been the traditional focus of public administration” (Brown 2005, page 248).

The advantages of the Internet for the dissemination of information have clearly indicated the possibility of increasing transparency in public life. As Kim et al (2005) state, technologies can supply important information more opportunely and contribute to administrative processes becoming more transparent. In the understanding of the OECD (2003), the greater capacity for broadcasting information over the Net has increased the pressure upon public administrations to practice greater transparency. The eEurope plans for 2002, 2005 and 2010 for the development of electronic government underline the improvement in transparency and presentation of accounts to citizens. Organisms such as the International Monetary Fund and the OECD have established codes for good practice, concerning transparency. Finally, for King (2006), as traditional concepts of democracy are communication-rich, the value of the potential of the Internet as an open and accessible agora is clear. However, a power shift to the users will not occur without political leadership. 
The article proposes a series of hypotheses concerning the factors which encourage town halls to disclose their financial information via the Internet. Firstly, it analyses, for the case of town halls, some of the classical hypotheses of accounting research, employed in pioneering studies (see, for example, Buzby, 1975; Singhvy and Desai, 1971; Zimmerman, 1977), or other more recent work (Caba et al., 2005; GinerInchausti, 1997; Gore, 2004; Laswad et al., 2005; Patten, 1991). These studies utilise as explanatory factors of disclosure the size of the entity, the use of financial markets for financing, the financial features of the entity and the influence of political aspects such as the degree of political competition, the political affiliation of the mayor or the fact of governing in minority (Baber, 1983; Clark, 1994; Evans and Patton, 1987; Ingram, 1984).

The present paper reformulates other classical hypotheses and proposes new factors which affect disclosure. Press visibility is a determinant of disclosure (Ingram, 1984; Laswad et al, 2005; Zimmerman, 1977), but in the case of e-disclosure we believe it more appropriate to analyse Internet visibility, measured using specific search engine tools (Drèze and Zufryden, 2004; Thelwall, 2001). Serrano-Cinca et al (2004) find a relationship between the strategic decision to exploit the Internet made by companies, as measured by the number of online services they offer their clients, and e-disclosure. Transferring this reasoning to the public sector, we hypothesise a positive relationship between e-government and e-disclosure. Politicians are responsible for implementing egovernment actions, as this is only in its incubus. Within a few years it will be a matter of routine to implant e-government actions; today, however, this often depends on politicians' political will. And, of all possible government actions, those which depend most heavily on the will of the Mayor and his or her governing team are precisely those related to electronic democracy.

Debreceny et al (2002) suggest some external factors, particular to each country, which may influence e-disclosure, while the present study considers as external factors the income level of citizens, their use of communication technologies or their sociopolitical commitment. We argue that the greater the income and eduactional level of citizens and the greater their socio-political commitment, the stronger will be their pressure upon their local authorities to disclose via the Internet, whose level of edisclosure will consequently increase. 
The paper is structured as follows. Section 2 includes a specific description of the general characteristics of local administrations in Spain. Section 3 presents the theoretical framework. Section 4 develops a set of hypotheses regarding the disclosure of information via the Internet by local public administrations. Section 5 presents the research design i.e. an empirical study employing data from Spanish town councils. Section 6 presents the results of testing the hypotheses. The final section offers the conclusions reached.

\section{LOCAL ADMINISTRATIONS IN SPAIN}

Spain is a regional state i.e. it is characterized by a substantial autonomy achieved without a profound restructuring of the state (Rodríguez-Pose, 2002). One characteristic is it asymmetry; this means its historical regions or regions with the greatest sense of national identity enjoy higher levels of autonomy, while the remaining Autonomous Communities enjoy an average level, although the gap has narrowed in recent years. Concretely, Spain comprises 17 Autonomous Communities, which control over $35 \%$ of total public sector expenditure. The municipalities are the basic local entities in the territorial organization of the State, whose governmental and administrative organs are the town halls. The government and the administration correspond to the town hall, comprised of the mayor and the councillors, who are elected by citizens via universal suffrage. The municipalities manage approximately $13.5 \%$ per cent of total public expenditure.

The town halls are autonomous and possess full legal personality, regulatory self-government powers and are responsible for organizing and developing the provision of the most immediate public services to citizens. Law 7/1985, on the Regulation of the Bases of Local Government establishes the minimum services which town halls must offer, depending on their population level. The services provided by Spanish local governments are similar to those delivered by almost all European Union cities. This said, only the larger municipalities participate in education and health services, which are the responsibility of the regional government; see Torres and Pina (2004) for a description of the local Spanish administration. Nevertheless, the town halls' administrative management is not limited to the provision of services, but also includes the preparation of budgets, presenting accounts and establishing links with citizens, 
companies and other governmental organisms.

Local government reform in Spain, initiated by Law 57/2003 on Measures for the Modernization of Local Government underlines the necessary application of information technologies in order to contribute to the transparency of government information. The Law refers to the role of technologies as a medium for the performance of administrative procedures and the presentation of documents.

In Spain, as in the rest of the world, advances have recently been made in promoting citizen participation, which is the very foundation for democratic development. Law 11/2007, which regulates Electronic Access by Citizens to Public Services, contributes toward bringing the administration closer to citizens and the interoperability of IT systems. This Law underlines the need to increase citizen participation and involvement and states that technologies are a medium for facilitating citizen participation.

Devolution is a general trend involving countries from many different geographical areas (Everingham et al., 2006; Rodríguez-Pose and Sandall, 2008). Spain forms part of this tendency. According to Rodríguez-Pose and Gill (2003) Spain, despite not being a federal state, is arguably the most decentralised state in Western Europe. There exists a long debate concerning the possible effect of devolution upon transparency. The reduced distance between politicians and their electorates can potentially increase political accountability, transparency and participation (RodríguezPose and Tijmstra, 2007). In general it is assumed a superior transparency of administrations that are 'closer to the people', but the empirical evidence is inconclusive (Rodríguez-Pose and Bwire, 2004). Ezzamel et al (2004) studied the relation between devolution and transparency in the UK case and concluded that devolution has produced more openness and transparency. They claim that devolution has significantly and unequivocally contributed to a more consultative, transparent and democratically accountable government in Northern Ireland, Scotland and Wales. However, in the Spanish case, Torres and Pina (2004, page 461) conclude that "Spain shows initiatives in territorial devolution but the absence of management devolution to line departments and managers, clear lines of responsibility and performance indicators, have turned initiatives such as the introduction of accrual accounting in the 1980s into superficial changes”. They argue that the lack of coherence between devolution and budgetary and 
accounting changes explains why Spain has not been able to transform the public sector as sharply as the UK. The case of Italy is similar, where Fedele and Ongaro (2008) conclude that, despite devolution, Italian regions have not made their administrative routines to be more accountable.

The other principal aspect of the debate concerns those factors alleged to affect disclosure and transparency following devolution. For Fedele and Ongaro (2008) transparency in regional governments following devolution is apparently influenced by the organisational capacity of the key organizations involved and by the audit and evaluation processes employed. The Scottish government administration practiced a higher degree of disclosure and accountability, such as value-for-money or performance auditing, while in Italy and Spain regional managerial capacity was reduced and audits concentrate on compliance with financial regulations.

\section{THEORETICAL FRAMEWORK}

Many factors, widely studied in accounting research, lead entities to disclose information (see, for example, Ahmed and Courtis, 1999; García-Meca et al, 2005; Gibbins et al, 1990; Giner-Inchausti, 1997; Healy and Palepu, 2001; Verrecchia, 2001). For public bodies, a key aspect is the regulation of the public right to access to information (Gore, 2004; Ingram and DeJong, 1987). Various countries have passed "Freedom of Information Acts" (FOIAs) which regulate the right to free access to information regarding public administrations and whose objectives include accountability to citizens, thereby contributing to transparency in public administration (Turle and Horden, 2005).

In the public sector, the voluntary provision of information has been seen as a way of limiting conflicts between citizens and politicians and forms part of agency theory (Banker and Patton, 1987; Leftwich et al, 1981; Zimmerman, 1977). Agency relationships in the public sector provide incentives to public sector managers to voluntarily disclose information that allows their actions to be monitored (Laswad et al, 2005).

Numerous studies have analysed the influence of political factors upon information disclosure. Ingram and DeJong (1987) perform an empirical analysis of the 
relationship between local government financial disclosures and the economic incentives of political managers. Baber and Sen (1984) study the influence of the political process upon the adoption of standard reporting methods. Giroux (1989) proposes three disclosure indices which summarise financial disclosure and different variables which affect these indices, related to political competition, bureaucratic power and political structure.

Another theory which explains the voluntary revelation of information by public administrations is legitimacy theory. Legitimacy is defined as "a generalised perception or assumption that the actions of any entity are desirable, proper, or appropriate within some socially constructed system of norms, values, beliefs and definitions” (Suchman, 1995, page 574). The voluntary disclosure of information has been considered to award legitimacy to companies and entities (Brown and Deegan, 1998; Patten, 1992; Woodward et al, 1996).

Numerous articles have dealt with Internet financial reporting (Ashbaugh et al, 1999; Debreceny et al, 2002; Deller et al, 1999; Larrán and Giner, 2002; Laswad et al, 2005; Lymer, 1999; Meijer, 2007; Pirchegger and Wagenhofer, 1999; Xiao et al, 2004). Healy and Palepu (2001) are correct in predicting the increasing use of the Internet for the voluntary disclosure of information. According to Jones and Xiao (2004, page 238), "the Internet has the power to revolutionise external reporting".

Laswad et al (2005) analyse determinants of Internet financial reporting by local government authorities; their study is based on New Zealand practices, and the authors propose further studies in other countries, which would help to develop a comprehensive and predictive model of Internet disclosure for the public sector.

\section{HYPOTHESES}

Having reviewed the literature on e-disclosure, we gathered the factors which lead local public administrations to disclose financial information via the Internet into three dimensions. The first dimension is the characteristics of the entity, and corresponds to the first three hypotheses: size (H1), municipal bond (H2) and financial features (H3). The second represents political aspects and includes the hypotheses regarding the political situation (H4) and e-government (H5). The remaining hypotheses 
(H6, H7 and H8) are grouped within the environmental dimension.

We will present, for each hypothesis, their underlying theoretical justifications and the results obtained in various empirical studies.

\subsection{Disclosure incentives: size}

Classical theories of financial information disclosure predict a positive and significant relationship between size and disclosure. In agency theory, conflicts of interest are more likely in larger cities and the advantage of disclosing information is correspondingly greater. In line with Zimmerman (1977, page 132) "we would expect small cities to publish annual reports less frequently than large cities”. Legitimacy theory also propounds a positive relationship between size and disclosure, as the varied pressures upon town halls to be transparent are greater in larger councils. In the business sector, this theory has been tested by Adams et al (1998) and Patten (1991). Furthermore, West (2000) and Torres et al (2005) have argued that the publishing of information on the Internet represents an innovation, and larger administrations have greater possibilities of innovation than their smaller counterparts.

From the empirical point of view, a meta-analysis of 29 studies of disclosure, performed by Ahmed and Courtis (1999) confirms significant and positive relationships between disclosure levels and size, in the majority of such research. The bibliographical review by Larrán and Giner (2002) reaches the same conclusion. In the field of public administrations, Ryan et al (2002) find that size is positively associated with annual disclosure reports by Australian local governments. The study made by Ingram and Robbins (1988) of American local governments also relates the extent of disclosure to size. Christiaens (1999) and Magann (1983) find similar results. In summary, there exist numerous theoretical arguments and empirical evidence which support the following hypothesis:

H1: There is a positive association between size and e-disclosure. 


\subsection{Disclosure incentives: financing via the markets}

Local authorities have the possibility of using the financial markets to obtain financing through debt emission. Creditors both demand and value informational transparency. In accordance with agency theory, when public administrations recur to these markets they fulfil greater demands for information disclosure, in order to minimise conflicts of interest between creditors and politicians (Baber and Gore, 2006; Baber and Sen, 1986; Gore, 2004; Zimmerman, 1977) analyse the relationship between the level of financial information offered by local governments and the use of the bond markets, finding a positive relationship between the two variables. In the business sector the empirical evidence shows a significant and positive relationship between listing status and disclosure levels (Ahmed and Courtis, 1999). Ettredge et al (2001) find a positive relationship between the degree of voluntary information disclosure and the need for companies to obtain new financing in the markets. We propose the following hypothesis:

H2: There is a positive association between issuing municipal bonds and edisclosure.

\subsection{Disclosure incentives: financial features}

For the business world, numerous studies analyse the relationship between disclosure and financial features; Singhvi and Desai (1971) argue that companies with the best performance in financial terms, such as profitability, sales or profits, will have a greater interest in publishing their financial information, in order to present a better image to their shareholders or potential investors. Concepts such as profitability, sales or profits cannot be easily applied to public administrations, but there exist numerous indicators of performance (Behn, 2003).

When testing the relationship between financial features and disclosure the results are not conclusive (Ahmed and Courtis, 1999). While a positive relationship is documented by Roberts (1992), Neu et al (1998) find that disclosure increases when performance declines. In other studies, such as that by Giner-Inchausti (1997), statistically significantly results are not observed. Although in some firms belonging to concrete sectors and countries it has indeed been shown that companies with the best 
annual accounts reveal more information we do not expect this to be the case of Spanish town halls of a certain size. To expect that entities with brilliant statements of accounts reveal more than those public administrations which are undergoing some type of financial difficulty would be a manifestation of the lack of democratic maturity within those Spanish public administrations.

We propose the following hypothesis:

H3: The financial features in local governments is independent of e-disclosure.

\subsection{Disclosure incentives: municipal policy}

Local public administrations are governed by politicians, and the influence of both political ideas and the different situations facing local authorities may be reflected in aspects such as e-disclosure. An important circumstance is whether or not the local authority governs in majority and, in addition, its degree of political competition (see, for example, Baber, 1994; Baber and Sen, 1984; 1986; Clark, 1994; Evans and Patton, 1987; Ingram, 1984; Laswad et al, 2005; Zimmerman, 1977).

However, from the empirical point of view the results are not conclusive. Evans and Patton (1987, page 149) find that "high political competition has an unexpectedly negative sign in the overall sample”. Laswad et al (2005) find that there is greater political competition to become councillors in town halls which disclose information via the Internet than in those which do not. Giroux (1989) finds evidence that accounting disclosures are at least marginally related to political/economic incentives. The following hypothesis is therefore proposed:

H4: There is a positive association between political factors affecting local governments and e-disclosure.

\subsection{Disclosure incentives: e-government}

A broad definition of e-government must include electronic communication, both within public administrations and with the various actors with which they interact,

such as companies, citizens and other administrations (Conroy and Evans-Cowley, 2006; Layne and Lee, 2001; Moon, 2002; Norris and Moon, 2005; van den Berg and van 
Winden, 2002). Marche and McNiven (2003, page 75) provide a precise definition, which includes e-services and e-contents: "e-government is the provision of routine government information and transactions using electronic means, most notably those using Internet technologies, whether delivered at home, at work, or through public kiosks”.

Firms which have decided strongly in favour of a strategic use of the Internet disclose more financial information via this medium, as Serrano-Cinca et al (2004) state. They find that financial entities which provide advanced electronic banking services are also leaders in e-disclosure. Debreceny et al (2002) find that technology is a determinant of Internet financial reporting. For Xiao et al (2004), greater familiarity with the Internet and an interest in being a leader in the employment of new technologies are circumstances which favour e-disclosure. Politicians are responsible for implementing egovernment actions. Thus, Internet financial reporting requires public administrations to have sufficient knowledge, political will and technological resources, and those councils which have implemented more e-government initiatives will tend to disclose more financial information or, in formal terms:

H5: There is a positive association between e-government and e-disclosure.

\subsection{Disclosure incentives: Internet visibility}

Various authors have argued that visibility is a determining factor of disclosure (Ingram, 1984; Laswad et al, 2005; Lim and McKinnon, 2003; Zimmerman, 1977). The study by Zimmerman (1977) shows that press and public media influence the agency relationship. Lim and McKinnon (2003) find a positive correlation between political visibility and voluntary disclosure of financial information. Laswad et al (2005) find a positive association between the frequency of press reporting of local government activities and the voluntary use of Internet financial reporting by local authorities. Legitimacy theory also argues that the most visible entities will disclose more information, due to the pressures they face (Cormier et al, 2004; Magness, 2006).

We shall include a different nuance, since we consider that when studying edisclosure it is more appropriate to talk of Internet visibility, as a measure of the popularity of a webpage or site. Visibility on the Internet is measured by variables 
which calculate the positioning of the website in search engines and also by calculating the impact of the site upon social networks, such as weblogs. Internet visibility is a key aspect in e-commerce, since those shops which are most highly visible receive more visitors, who of course are potential customers (Drèze and Zufryden, 2004; Thelwall, 2001).

We believe that Internet visibility may be an explanatory factor with regard to information disclosure, since local public administrations which make greater use of the Internet are subjected to greater pressure from Internet users and, in response to such pressure, are more prone to disclose information on their websites. We propose the following hypothesis:

H6: There is a positive association between Internet visibility and e-disclosure.

\subsection{Disclosure incentives: citizens' wealth.}

Circumstances which are external to the local public administration, such as the economic level of its citizens, may affect the decision to disclose information. Technological and income level generally go hand in hand. In line with Ho (2002), in the specific case of Internet information disclosure, cities with a lower per capita income are less likely to adopt progressive web design, due to lower demand for web-based services. Other studies include per capita income as an explanatory variable (Cheng, 1992; Ingram, 1984; Ingram and Copeland, 1981; Robbins and Austin, 1986). In local authorities whose citizens make greater use of information technologies, an environment is created which stimulates governments to offer services and information, including edisclosure via the Internet. The greater the proportion of Internet users, the greater is that of citizens potentially receptive to the consultation of this type of financial information via the Internet.

We propose the following hypothesis:

H7: There is a positive association between citizens' wealth and e-disclosure.

\subsection{Disclosure incentives: citizens’ cultural level}

Other external aspects, such as citizens’ political awareness, or degree of social 
commitment or culture, or citizens' education level may affect information disclosure. A local authority whose citizens are highly socially and politically aware is more likely to publish financial information, as a result of the pressure they exert. Various researchers have demonstrated a relationship between social variables and information disclosure (Cheng, 1992; Debreceny et al, 2002; Ingram, 1984; Ingram and Copeland, 1981). Ingram and Copeland (1981) include in their study variables such as population composition, economic activity and employment concentration. Ingram (1984) and Cheng (1992) include in their studies the educational level of the population as an explanatory variable of disclosure. In the business world, using data for companies in 22 countries, Debreceny et al (2002) show that an index of the overall financial reporting environment, comprised of various cultural factors, is strongly significant in predicting e-disclosure.

McNeal et al (2007) analyse the influence of state-wide professional networks and interest groups upon the extent of e-disclosure, and emphasise the importance of certain types of interest groups i.e. those which strongly influence the expansion of edisclosure policies. Likewise, they claim that income and education, are also important factors in e-disclosure policy. According to Evans and Yen (2005, page 368), “countries with substantially lower levels of education will have users that are not intuitively familiar with basic screen forms." Chaudhuri et al (2005) find that a higher degree of educational attainment and whether one is a student are both positive and significant predictors of Internet subscription.

The following hypothesis is proposed:

H8: There is a positive association between citizens' cultural level and edisclosure.

\section{RESEARCH DESIGN}

This section presents the sample used and justifies the variables selected to test the hypotheses of the empirical study.

\subsection{Sample}

The hypotheses were tested by a study of Spanish local public administrations. 
All provincial capitals and all town halls with over 70,000 inhabitants were considered. The sample employed to test the hypotheses comprises 92 local authorities (Table 1), and the data from their websites were compiled by the research team in June 2006.

\section{Table 1}

\subsection{Disclosure variables}

For each local public administration we completed a questionnaire comprised of 9 variables related to the disclosure of financial information (Table 2). To select the variables we reviewed Spanish legislation regarding local government financial disclosure (Cárcaba-García et al, 2002). The 9 variables include information concerning the individual budget of the town hall, (BUDG1), the consolidated budget (BUDG2), the budget of dependent entities (BUDG3), the budget disaggregated by economic, functional or organic classification (BUDG4), budgetary information regarding investment, borrowing or revenue and expenditure (BUDG5), the individual annual accounts (ACC1), the consolidated annual accounts (ACC2), the annual accounts of dependent entities (ACC3) and the audit report (AUDIT).

$* * * *$

Table 2

Table 2 shows that 49 of the 92 town halls (i.e. 53.26\%) disclose financial information regarding their budgets or annual accounts (e-DISCL). Some town halls present their financial data exquisitely, while others have barely adequate websites which include no financial information. Slightly more than half of the town halls (53.26\%) make their individual budgets available on the Internet (BUDG1). 35.86\% of local authorities disclose their consolidated budgets (BUDG2). Budgets disaggregated by budgetary items are presented by 28.26\% (BUDG4), while only two offer their audit report (AUDIT) and only one presents its complete annual accounts on its website 
(ACC1).

\subsection{Hypothesis-testing variables}

The variables utilised to test the hypotheses and their definitions are shown in Table 3.

$* * * *$

Table 3

To measure the size of the entity (Hypothesis 1), population (POPUL) and budget revenue (REVEN) were employed. POPUL was obtained from the Spanish Statistics Institute and REVEN from the Spanish Ministry for Public Administration. The data are for 2004.

The variable BOND is a dichotomic variable which assigns the value of 1 if the town hall has municipal bonds in circulation and 0 otherwise (Hypothesis 2). In Spain, Royal Decree 705/2002 regulates the Authorisation of Public Debt Issue by Local Authorities. The public debt issued by local authorities must be similar to State debt issue, with regard to the conditions established. Public debt issue requires authorisation from the Ministry of Economy, which checks the financial-economic situation of the local authority. Concerning size, any municipality may issue debt. The only difference is that entities with more than 200,000 inhabitants and which periodically issue public debt can voluntarily take advantage of a fast-track request procedure. The information source is the Central Bank of Spain.

To analyse the influence of financial features upon e-disclosure (Hypothesis 3), five variables were obtained. The ratio of self-financing (SELF) measures taxes on current income. If this ratio is high, it means that the town hall is little dependent on other public administrations for sources of financing. The ratio of financial expenditure to total expenditure (FINANC) is indicative of the entity's debt, and the lower its value the better for the entity. The ratio of operating expenses to total expenses (OPERAT) has been included; the values of the ratio should be low, since this would indicate that the expenditure item for the maintenance and operation of services is low in relation to 
the total. INV is the ratio of investment per inhabitant and TAX is the ratio of tax revenue per inhabitant. The source for this information was the Spanish Ministry for Public Administration.

To analyse the influence of political aspects upon e-disclosure (Hypothesis 4), three variables were obtained. The degree of political competition was measured by the ratio of candidates presented to councillors elected (COMP). The variable COAL measures coalition situations in the town hall. The value of 1 is assigned to governments with an absolute majority, 2 to governments who enjoy a relative majority and govern alone, 3 to a two-party coalition and 4 to a multi-party coalition. The variable POLOR assigns a score according to the position of the government on the left-right spectrum. That is to say, 0 indicates a right-wing government with an absolute majority and 8 represents a left-wing government with an absolute majority. Intermediate values indicate coalitions with centrist or nationalist parties.

Hypothesis 5, regarding e-government, was tested using three variables (eSERV, eCONT and eDEM). Each of them measure different aspects of the e-government dimension. The 3 variables were constructed by adding together a set of distinct items. A count was made of the number of transactions which citizens are able to perform via the Internet (eSERV), including the services listed in the eEurope 2005 Action Plan, a project endorsed by the European Council of Ministers and aimed at developing modern public services. There is a maximum of 18 administrative procedures, which range from applications for building licences to the obtaining of electoral register enrolment.

E-government offers much more than shorter queues; according to the European Commission (2005, page 1) "the public sector can be made more open and transparent, delivering governments which are more comprehensible and accountable to citizens”, and thus a checklist was completed of the contents offered on the municipal website (eCONT). . eCONT measures the general information which town halls supply to citizens (geographic data and access to the municipality, transport, tourist information, the weather forecast, etc.), as well as information regarding the internal organisation of the entity. The checklist was established by Serrano-Cinca et al (2003) and includes 24 highly varied aspects, ranging from weather forecasts to traffic reports.

The variable eDEM measures the number of e-democracy actions implemented. 
eDEM includes 5 instruments through which citizens may give their opinion or participate in decision-making, and returns a score between 0 and 5 . These instruments are: forums, a citizens' mailbox, online surveys, chat rooms, and experience of electronic voting.

Hypothesis 6 proposes measuring Internet visibility, as an alternative to press visibility. Press visibility is usually measured by counting the number of news items concerning the local authority which appear in the press, as Laswad et al (2005) state. In the case of the Internet, a visible website is one which receives a large number of backlinks from other websites. The number of backlinks to a website is an important factor in the ranking process employed by search engines. The creators of Google, Brin and Page (1998, page 109), recognize that “Academic citation literature has been applied to the Web, largely by counting citations or backlinks to a given page. This gives some approximation of a page's importance or quality." An estimation of these backlinks may be obtained by utilising a special command possessed by some search engines, and consists of entering "linkdomain”, followed by the website address (Brock and Zhou, 2005). We entered this instruction using the MSN search engine (LINKS). Municipal website visibility in the Blogosphere was also measured, counting the number of posts on blogs according to the Technorati search engine (POSTS). Only those comments which include the municipal Internet address were counted, and not those which merely offered an opinion of the city.

Hypothesis 7 concerns the income level of citizens. Disposable family income per inhabitant of the council (WEALTH) was selected to measure income level. The variable was scaled in 10 brackets, on the basis of data provided by the Spanish Statistics Institute. With regard to the technological level of citizens, reliable data do not exist in Spain at the municipal level, but only for the region to which the local council belongs.

Education level and socio-political commitment (Hypothesis 8) was measured by 3 variables. The first is voter turnout at elections (VOTE). The degree of community involvement was measured by calculating the number of civic associations in the municipality, divided by the number of inhabitants (ASSOC). The third variable is the average number of years of education (EDU), calculated as in the work by Barro and Lee (2001). The data were taken from the annual social report published by the research 
department of a financial entity, La Caixa.

\subsection{Statistical techniques employed}

ANOVA and a non-parametric test of means were used as analysis techniques to test the hypotheses. An analysis was made of whether significant differences exist between the 49 local authorities which disclose financial information via the Internet and the 43 which do not. The variable eDISCL assigns the value of 1 if the authority discloses and 0 if it does not. Table 4 presents the results of an exploratory analysis, of an ANOVA test of means and of a non-parametric Mann-Whitney test.

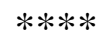

Table 4

$* * * *$

In the case of the categorical variable BOND (issues debt), a contingency table was calculated, as shown in Table 5. Pearson's chi-square was calculated to analyse whether the differences are significant.

Table 5

\section{RESULTS AND DISCUSSIONS}

The fulfilment of the hypotheses proposed is analysed below.

\subsection{Result of the hypothesis test}

Table 4 shows that councils which disclose financial information are, on average, almost three times larger than those which do not. These differences are significant in the two variables regarding size, POPUL and REVEN, for both the parametric ANOVA test and the non-parametric Mann-Whitney test. We may conclude that the data support Hypothesis 1 i.e. there exists a positive association between size and e-disclosure. 
With regard to the fulfilment of Hypothesis 2, Table 5 shows that only 12 councils issue debt (BOND). Of these, 11 disclose and 1 does not. The differences are statistically significant. Although no legal restrictions exist, it is true that only large town halls have made use of this financing possibility; Burgos, which has 170,000 inhabitants, is the smallest. When a statistical test is performed, a statistically significant relation is observable between municipality size and BOND. The cause is no doubt the financial complexity and the cost of access to these financial markets.

With regard to the fulfilment of Hypothesis 3, the results of the hypothesis test found no relation between the 5 variables analysed (INV, TAX, SELF, FINANC, and OPERAT) and e-disclosure. The result is in line with those of the studies mentioned above, since it confirms the belief that many of them are usually inconclusive. We believe that the lack of a relationship between financial features and disclosure is a reflection of maturity, characteristic of cities of the size analysed.

With regard to the political aspects affecting local public administrations (Hypothesis 4), the candidate/councillor ratio (COMP) is greater in local authorities which disclose financial information, and these differences are statistically significant. Given such result, indications exist that certain political factors affecting town halls are related to the disclosure of financial information. Although there also exist positive differences between those who govern in coalition (COAL) these are not statistically significantly. Finally, political orientation (POLOR) is not a significant variable.

With regard to Hypothesis 5, concerning local authority Internet strategy, Table 4 shows that, on average, local authorities which disclose financial information provide almost twice as many services to citizens via the Internet (eSERV) as those which do not. The differences are significant, and there are also significant differences in the eCONT variable, which measures the contents of the municipal website. Table 4 also shows significant differences regarding the variable which measures the number of municipal initiatives encouraging electronic democracy (eDEM). The data support hypothesis 5 i.e. there is a positive association between e-government and e-disclosure.

With regard to the Internet visibility variables (Hypothesis 6), Table 4 shows that, on average, local authorities which disclose financial information are more visible, as measured by the number of incoming links (LINKS) and the posts on blogs linked to 
the municipal website (POSTS). The differences are also significant. It should be noted that these two variables do not meet the requirements of normality and non-parametric tests must be employed.

Turning to Hypothesis 7, Table 4 shows that, on average, residents in cities which disclose financial information have relatively high incomes (WEALTH). The differences are statistically significant. With regard to Internet access we have already stated in the paper that we do believe that this is relevant and important but, unfortunately, such data are not available in Spain at municipal level. What we are however able to do is calculate Pearson's correlation coefficient between income level at the Autonomous Community level and the level of Internet access. The correlation coefficient displays a high, positive and statistically significant value (0.868). The strong relation between income and access to the Internet is thereby confirmed; in other words, and at least in Spain, money matters. Prudence thus dictates the extraction of no further conclusions.

In the case of education level and socio-political factors, (Hypothesis 8) Table 4 shows that, on average, local authorities which disclose financial information are located in regions with a high level of community involvement (ASSOC). However, these differences are not significant. Neither can significant differences be observed with regard to voter turnout (VOTE), which is slightly higher in the case of town halls least prone to disclose information. Paradoxes occasionally occur; for example, turnout is lower in countries in which democracy is longerstanding (Franklin, 2004). The empirical study finds that the relationship between the average number of years of education (EDU) and e-disclosure is positive and statistically significant at $1 \%$ level.

\subsection{Regression results}

The relationships between the variables were analysed by calculating the Pearson and Spearman correlation coefficients for the 19 continuous variables (Table 6).

\section{Table 6}


When analysing Table 6, the positive and significant correlation between the variables of size and e-government via the Internet is striking. One explanation is that the implementation of services to citizens via the Internet is costly, and thus larger councils are better equipped to offer the possibility of performing a larger number of transactions on their websites.

It is only to be expected that there exists a positive correlation among the three egovernment variables (eDEM, eSERV and eCONT), since town halls which offer many services online frequently incorporate informational content into their web pages and are notable for their e-democracy initiatives. This is not always the case, however; for example, some town halls in tourist areas offer a complete range of information, but nevertheless scarcely develop the online procedures aspect. Pearson's correlation coefficient between eDEM and eSERV is 0.22 ; between eDEM and eCONT it is 0.30 ; and between eSERV and eCONT it is 0.69 . These values are positive and statistically significant, but in line with expectations.

Virtual shops use a number of strategies to increase their Internet visibility. One of them is to offer free content; one example might be a mountain-climbing equipment shop which edits an online magazine and maintains a forum. Municipal web sites who offer substantial content also increase their Internet visibility. For instance, those who have placed online the catalogue of paintings being displayed in the local museum will increase their Internet visibility. This is why we expect to find a positive correlation between the variables which measure e-government and those which measure Internet visibility. Nevertheless, website visibility can also be increased using Search Engine Optimization (SEO) techniques; these require the website to be redesigned in technical terms. Table 6 shows that the highest value of Pearson's correlation coefficient between the variables eSERV and LINKS is 0.4 . There is a positive and statistically significant correlation between Internet visibility and electronic government, but no more than expected.

It can be observed that EDU (average number of years of education) is related to the other social variables i.e. ASSOC (the Number of community associations, divided by the number of inhabitants) and VOTE (Voter turnout), which seems coherent. Concerning the remaining correlations EDU is related to WEALTH, which likewise is coherent, since university graduates have higher incomes. From among the variables 
related to electronic government, the only one which is positively correlated to EDU is eCONT, which measures the content of the municipal website. No correlation was detected between EDU and eSERV, which measures the services provided by town halls via the Internet. Neither was any correlation found between EDU and eDEM, or electronic democracy. Cities such as Pozuelo, in which the variable EDU attains an average of 12.57 years, compared to an average of scarcely 8.48 years in other cities. $43 \%$ of the residents of Pozuelo, a city on the outskirts of Madrid, are full university graduates, while the figures for other municipal districts exceed with difficulty $5 \%$. These figures motivated us to analyse the subject in greater depth.

Although the data indicate that a relation exists between citizens' educational level and e-disclosure, the confidence level is low. Thus, the supply of and demand for information and municipal services is unbalanced. Katchanovski and La Porte (2005) coined the term "Potemkin E-villages" to refer to government webpages which nobody consults and are little more than an elaborate facade designed to create the impression of open electronic government. We believe that the opposite effect is more worrying: some Spanish cities have inhabitants with a high educational level and social commitment, but whose municipal webpages do not meet the expectations and needs of citizens, since they do not offer services via the Internet which would no doubt be in high demand. We believe that these town halls should make an effort to improve their municipal webpages.

We now attempt to model the factors influencing e-disclosure, employing a logistic regression. The dependent variable (eDISCL) assigns the value of 1 if the local council discloses financial information via the Internet and 0 if it does not. Table 7 presents the results of the regression.

$* * * *$

Table 7

Concerning logistic regression, we employed a model selection technique in order to determine the variables which form part of the model, in an attempt to identify a parsimonious model. We performed the usual tests for multicollinearity and likewise the 
variance inflation factor (VIF). According to Kleinbaum et al. (1988), multicollinearity exists if the VIF is greater than 5. The test did not detected multicollinearity in the variables which comprise the final model; the VIF values range between 1.05 and 1.21.

The significant variables which enter the model are size- measured by the logarithm of the number of inhabitants in the local authority (LnPOPUL), the income level of citizens (WEALTH) and the number of e-democracy actions implemented (eDEM). Larger town councils which have chosen the political option to encourage edemocracy and whose citizens enjoy a relatively high standard of living tend to edisclose more. The signs of the coefficients are those expected i.e. always positive. Nagelkerke's $\mathrm{R}^{2}$ is 0.328 , in line with similar studies.

We shall attempt to make a parsimonious interpretation of the results obtained. Large cities have the resources available to offer more services to their citizens via the Internet. The disclosure of financial information forms part of their strategy, as simply another service to citizens. Town halls which politically support e-democracy initiatives are also the most transparent with regard to Internet financial reporting. A higher standard of living of citizens is reflected in greater utilisation of technologies and a higher demand for services and information, including financial data, via the Internet. Edisclosure is a question of size, political will and citizens' standard of living.

\section{CONCLUSIONS}

More and more, the Internet is the medium chosen by public administrations to disclose financial information to citizens. The present study proposes hypotheses regarding the factors which encourage local authorities to report financial information via the Internet. The hypotheses were tested in an empirical study of Spanish town councils.

The first group of hypotheses concerns the characteristics of town halls. We suggest that larger councils, which obtain finance in the financial markets, are more likely to disclose financial information via the Internet. The data support the hypotheses proposed. No statistically significant relationship is apparent between e-disclosure and financial features of the entity.

The second group of hypotheses concerns political aspects. It is found that 
councils which have made greater efforts to implement e-government are more likely to disclose financial information via the Internet. There exist indications that political factors affecting town halls are related to Internet financial reporting, and in particular a statistically significant association can be observed between the political competition and e-disclosure.

The third group of hypotheses concerns the local environment. It is found that local councils whose residents have a high standard of living and have a high education level disclose more financial information via the Internet.

Laswad et al (2005) find, for New Zealand local governments, that citizens' income level, media pressure and the type of entity influence e-disclosure. Our study confirms these hypotheses, although media pressure was measured by Internet visibility. New explanatory hypotheses at the level of e-government and e-democracy have been added. Styles and Tennyson (2007) examine the accessibility of local government financial reports on the Internet for a sample of US municipalities of varying size. The accessibility of the data is positively related to both the number of residents and residents' income per capita. Municipalities in a poorer financial position provided less convenient access to town hall financial data on the Internet, which indicates the continued influence of debt markets on public sector financial reporting. Our study found no relation between financial position and e-disclosure. We also confirm that municipality size, citizens' economic level and the existence of municipal bonds affect the publication of financial data online.

E-disclosure was modelled using logistic regression, which included as explanatory factors size (measured by the number of inhabitants), political will (measured by councils' experience with e-democracy) and the local standard of living (measured by citizens' per capita income).

Finally, it must be emphasised that the level of e-disclosure in Spanish local administrations is still very low. The present study shows that the largest councils disclose most information, but to report information on a website is neither especially costly nor complicated. Traditionally, it has been expensive to disclose accounting information, but the Internet provides an economical channel to do so. We must recognise that many adolescents have blogs whose content is greater than that of the 
financial information included in the websites of cities with hundreds of thousands of inhabitants. We believe that politicians must make increasing use of the Internet to disclose financial information. 


\section{REFERENCES}

Adams C, Hill WY, Roberts CB, 1998, “Corporate social reporting practices in western Europe: legitimating corporate behaviour?” The British Accounting Review 30(1) 1-21

Ahmed K, Courtis JK, 1999, “Associations between corporate characteristics and disclosure levels in annual reports: a meta analysis”, British Accounting Review 31 35-61

Ashbaugh H, Johnstone KM, Warfield TD, 1999, “Corporate Reporting on the Internet”, Accounting Horizons 13 241-257

Baber WR, 1983, “Towards understanding the role of auditing in the public sector”, Journal of Accounting and Economics 5(3) 213-227

Baber WR, 1994, "The influence of political competition on governmental reporting and auditing”, Research in Governmental and Nonprofit Accounting 8. 109-127

Baber WR, Sen PK, 1984, "The role of generally accepted reporting methods in the public sector: An empirical test”, Journal of Accounting and Public Policy 3(2) 91-106

Baber WR, Sen PK, 1986, "The political process and the use of debt financing by state governments”, Public Choice 48 (3) 201-215

Baber, WR, Gore, AK, 2006, "Consequences of GGAP reporting requirements: evidence from municipal debt issues”, WP, University of Oregon

Banker RD, Patton JM, 1987, “Analytical agency theory and municipal accounting: an introduction and an application”, Research in Governmental and Nonprofit Accounting 3(B). 29-50

Barro R J, Lee J W, 2001, "International data on educational attainment: updates and implications” Oxford Economic Papers 53 541-563

Behn RD, 2003, "Why measure performance? Different purposes require different measures”, Public Administration Review 63(5) 586-606

Brin S, Page L, 1998, "The anatomy of a large-scale hypertextual Web search engine”, Computer Networks and ISDN Systems 30(1-7) 107-117

Brock JKU, Zhou Y, 2005, "Organizational use of the Internet: Scale development and validation”, Internet Research 15(1) 67-87

Brown D, 2005, “Electronic government and public administration” International Review of Administrative Sciences 71(2) 241-254 
Brown N, Deegan C, 1998, "The public disclosure of environmental performance information - a dual test of media agenda setting theory and legitimacy theory", Accounting and Business Research 29(1) 21-41

Buzby SL, 1975, “Company size, listed versus unlisted stocks, and the extent of financial disclosure”, Journal of Accounting Research 13 16-37

Caba C, López A, Rodríguez MP, 2005, “Citizens’ access to on-line governmental financial information: Practices in the European Union countries", Government Information Quarterly 22 258-276

Cárcaba-García A, López-Díaz A, Pablos-Rodríguez JL, 2002, “Improving the disclosure of financial information in local governments”, International Public Management Review 3(1) $22-40$

Chadwick A, 2003, "Bringing e-Democracy back in: why it matters for future research on eGovernance” Social Science Computer Review 21(4) 443-455

Chaudhuri A, Flamm K S, Horrigan J, 2005, “An analysis of the determinants of internet access” Telecommunications Policy 29(9-10) 731-755

Cheng RH, 1992, 'An empirical analysis of theories on factors influencing state government accounting disclosure', Journal of Accountancy and Public Policy 11(1) 1-42

Christiaens J, 1999, "Financial accounting reform in Flemish municipalities: an empirical investigation”, Financial Accountability \& Management 15(1) 21-40

Clark TN, 1994, "Program for a new public choice”, Research in Governmental and Nonprofit Accounting 8 3-28

Conroy MM, Evans-Cowley J, 2006, "E-participation in planning: an analysis of cities adopting on-line citizen participation tools", Environment and Planning C: Government and Policy 24(3) 371-384

Cormier D, Gordon I, Magnan M, 2004, “Corporate environmental disclosure: contrasting management's perceptions with reality?” Journal of Business Ethics 49(2) 143-165

Debreceny R, Gray GL, Rahman A, 2002, “The determinants of Internet financial reporting”, Journal of Accounting and Public Policy 21(4-5) 371-394

Deller D, Stubenrath M, Weber C, 1999, “A survey on the use of the Internet for investor relations in the USA, the UK and Germany”, The European Accounting Review 8 351364

Drèze X, Zufryden F, 2004, "Measurement of online visibility and its impact on Internet traffic”, Journal of Interactive Marketing 18(1) 20-37 
Ettredge M, Richardson VJ, Scholz S, 2001, "The presentation of financial information at corporate Web sites”, International Journal of Accounting Information Systems 2 149168

European Commission, 2005, eEurope Action Plan, E-government. Retrieved February 8, 2007, from http://europa.eu.int/information_society/eeurope/2005/all_about/egovernment/index_e n.htm.

Evans D, Yen C D, 2005, "E-government: an analysis of implementation: Framework for understanding cultural and social impact” Government Information Quarterly 22(3) 354-373

Evans JH, Patton JM, 1987, "Signalling and monitoring in public-sector accounting disclosure”, Journal of Accounting and Public Policy 8(3) 199-217

Everingham J-A, Cheshire L, Lawrence G, 2006, "Regional renaissance? New forms of governance in nonmetropolitan Australia" Environment and Planning C: Government and Policy 24(1) 139-155

Ezzamel M, Hyndman N S, Johnsen Å, Lapsley I, Pallot J, 2004, “Has Devolution Increased Democratic Accountability?” Public Money and Management 24(3) 145-152

Fedele P, Ongaro E, 2008, “A Common Trend, Different Houses: Devolution in Italy, Spain and the UK” Public Money and Management 28(2) 85-92

Franklin MN, 2004, Voter Turnout and the Dynamics of Electoral Competition in Established Democracies Since 1945. Cambridge: Cambridge University Press.

García-Meca E, Parra I, Larrán M, Martínez I, 2005, “The explanatory factors of intellectual capital disclosure to financial analysts”, European Accounting Review 14(1) 63-94

Gibbins M, Richardson A, Waterhouse J, 1990, “The management of corporate financial disclosure: opportunism, ritualism, policies and processes”, Journal of Accounting Research 28(1) 121-143

Giner Inchausti B, 1997, "The influence of company characteristics and accounting regulation on information disclosed by Spanish firms”, European Accounting Review 6(1) $45-68$

Giroux G, 1989, "Political interests and governmental accounting disclosure”, Journal of Accounting and Public Policy 8(3) 199-217

Gore AK, 2004, “The effects of GAAP regulation and bond market interaction on local government disclosure”, Journal of Accounting and Public Policy 23(1) 23-52 
Healy PM, Palepu KG, 2001, “Information asymmetry, corporate disclosure, and the capital markets: a review of the empirical disclosure literature”, Journal of Accounting and Economics 31(1-3) 405-440

Ho AT, 2002, "Reinventing local governments and the e-Government initiative”, Public Administration Review 62(4) 410-420

Ingram RW, 1984, "Economic incentives and the choice of state government accounting practices”, Journal of Accounting Research 22 (1) 126-144

Ingram RW, Copeland RM, 1981, "Municipal accounting information and voting behaviour”, The Accounting Review 56(4) 830-843

Ingram RW, DeJong DV, 1987, “The effect of regulation on local government disclosure practices”, Journal of Accounting and Public Policy 6(4) 245-270

Ingram RW, Robbins WA, 1988, "Financial reporting practices of local governments: an overview”, Government Finance Review, April, pp. 17-21

Jones MJ, Xiao JZ, 2004, "Financial reporting on the Internet by 2010: a consensus view”, Accounting Forum 28(3) 237-263

Katchanovski I, La Porte T, 2005, “Cyberdemocracy or Potemkin E-Villages? Electronic Governments in OECD and Post-Communist Countries” International Journal of Public Administration 28(7/8) 665-681

Kim P S, Halligan J, Cho N, Oh C H, Eikenberry A M, 2005, "Toward Participatory and Transparent Governance: Report on the Sixth Global Forum on Reinventing Government" Public Administration Review 65(6) 646-654

King J, 2006, "Democracy in the Information Age" Australian Journal of Public Administration 65(2) 16-32

Kleinbaum D G, Kupper L L, Muller K E, 1988 Applied Regression Analysis and other Multivariate Analysis Methods (PWS-Kent Publishing Company, Boston, MA)

Larrán M, Giner B, 2002, “The use of Internet for corporate reporting by Spanish companies”, The International Journal of Digital Accounting Research 2(1) 53-82

Laswad F, Fisher R, Oyelere P, 2005, “Determinants of voluntary Internet financial reporting by local government authorities”, Journal of Accounting and Public Policy 24(2) 101121

Layne K, Lee J, 2001, “Developing fully functional e-government: a four stage model”, Government Information Quarterly 18(2) 122-136 
Leftwich RW, Watts RL, Zimmerman JL, 1981, "Voluntary corporate disclosure: the case of interim reporting”, Journal of Accounting Research, 19 supplement 50-77

Lim S, McKinnon J, 2003, "Voluntary disclosure by NSW statutory authorities: the influence of political visibility”, Journal of Accounting and Public Policy 12(3) 189-216

Lymer A, 1999, "The Internet and the future of corporate reporting in Europe”, The European Accounting Review 8 289-302

Magann J, 1983, “Municipal financial disclosure: an empirical investigation”, Research for Business Decisions, 58, UMI Research Press

Magness V, 2006, “Strategic posture, financial performance and environmental disclosure. An empirical test of legitimacy theory”, Accounting, Auditing \& Accountability Journal 19(4) 540-563

Marche S, McNiven JD, 2003, "E-government and e-governance: The future isn't what it used to be”, Canadian Journal of Administrative Sciences 20(1) 74-86

McNeal R, Schmeida M, Hale K, 2007, "E-disclosure laws and electronic campaign finance reform: Lessons from the diffusion of e-government policies in the States" Government Information Quarterly 24(2) 312-325

Meijer AJ, 2007, "Publishing public performance results on the Internet: do stakeholders use the Internet to hold Dutch public service organizations to account?” Government Information Quarterly 24(1) 165-185

Moon M J, 2002, “The Evolution of E-government among municipalities: Rhetoric or Reality?” Public Administration Review 62(4) 424-433

Neu D, Warsame H, Pedwell K, 1998, “Managing public impressions: environmental disclosure in annual reports”, Accounting, Organizations and Society 23 265-288

Norris DF, Moon MJ, 2005, “Advancing E-Government at the grassroots: tortoise or hare?” Public Administration Review 65(1) 64-75

Organisation for Economic Co-operation and Development (OECD), 2003, "The egovernment imperative: main findings”, OECD e-Government Studies, Paris, http://www.oecd.org/dataoecd/60/60/2502539.pdf

Patten DM, 1991, “Exposure, legitimacy, and social disclosure”, Journal of Accounting and Public Policy 10 297-308

Patten DM, 1992, “Intra-industry environmental disclosures in response to the Alaskan oil spill: a note on legitimacy theory”, Accounting, Organizations and Society 17 471-475 
Pirchegger B, Wagenhofer A, 1999, "Financial information on the Internet: a survey of the homepages of Austrian companies”, The European Accounting Review 8 383-395

Robbins WA, Austin KR, 1986, "Disclosure quality in governmental financial reports: an assessment of the appropriateness of a compound measure”, Journal of Accounting Research 24(2) 412-421

Roberts R, 1992, "Determinants of corporate social responsibility disclosure: an application of stakeholder theory”, Accounting, Organizations and Society 17 595-612

Rodríguez-Pose A, Bwire A, 2004, “The economic (in)efficiency of devolution” Environment and Planning A 36(11) 1907-1928

Rodríguez-Pose A, 2002 The European Union: Economy, society, and polity (Oxford University Press, Oxford)

Rodríguez-Pose A, Gill N, 2003, “The global trend towards devolution and its implications” Environment and Planning C: Government and Policy 21(3) 333-51

Rodríguez-Pose A, Sandall R, 2008, "From identity to the economy: analysing the evolution of the decentralisation discourse" Environment and Planning C: Government and Policy 26(1) 54-72

Rodríguez-Pose A, Tijmstra S.A.R., 2007, "Local economic development in Sub-Saharan Africa” Environment and Planning C: Government and Policy 25(4) 516 - 536

Ryan C, Stanley T, Nelson M, 2002, “Accountability disclosures by Queensland local government councils: 1997-1999”, Financial Accountability and Management 18(3) 261-289

Serrano-Cinca C, Mar Molinero C, Bossi A, 2003, “An approach to the measurement of intangible assets in public sector using scaling techniques”, Journal of Intellectual Capital 4(2) 249-275

Serrano-Cinca C, Mar Molinero C, Chaparro F, 2004, "Spanish savings banks: a view on intangibles”, Knowledge Management Research \& Practice 2(2) 103-108

Singhvi SS, Desai HB, 1971, “An empirical analysis of the quality of corporate financial disclosure”, The Accounting Review 46 129-138

Styles A, Tennyson M, 2007, "The Accessibility of Financial Reporting of U.S. Municipalities on the Internet” Journal of Public Budgeting, Accounting \& Financial Management 19(1) 56-92

Suchman MC, 1995, "Managing legitimacy: strategic and institutional approaches”, Academy of Management Review, 20(3) 571-610 
Thelwall M, 2001, “Commercial Web Site Links”, Internet Research 11(2) 114-124

Torres L, Pina V, 2004, "Reshaping the Public Administration: the Spanish Experience Compared to the UK” Public Administration 82(2) 445-464

Torres L, Pina V, Acerete B, 2005, "E-government developments on delivering public services among EU cities”, Government Information Quarterly 22(2) 217-238

Turle M, Hordern V, 2005, “Introduction to Freedom of Information Act”, Computer Law \& Security Report 21(5) 415-419

van den Berg L, van Winden W, 2002, "Should cities help their citizens to adopt ICTs? On ICT adoption policies in European cities" Environment and Planning C: Government and Policy 20(2) 263-279

Verrecchia RE, 2001, “Essays on disclosure”, Journal of Accounting and Economics 32(1-3) 97-180

Wang H, Rubin B L, 2004, "Embedding e-finance in e-government: a new e-government framework” Electronic Government, an International Journal 1(4) 362-373

West DM, 2000, Assessing e-government: the Internet, democracy, and service delivery by state and federal governments. Providence, RI: Taubman Center for Public Policy, Brown University.

Woodward DG, Edwards P, Birkin F, 1996, “Organizational legitimacy and stakeholder information provision”, British Journal of Management 7 329-347

Xiao Z, Yang H, Chow C, 2004, "Patterns and determinants of Internet-based corporate disclosure in China”, Journal of Accounting and Public Policy, 23(3) 191-225

Zimmerman JL, 1977, “The municipal accounting maze: an analysis of political incentives”, Journal of Accounting Research 15, Suppl., 107-144 


\begin{tabular}{|c|c|c|c|c|c|}
\hline Municipality & Website & Municipality & Website & Municipality & Website \\
\hline Albacete & albacete.com & Getxo & getxo.net & Pozuelo de Alarcón & ayto-pozuelo.es \\
\hline Alcalá de Henares & ayto-alcaladehenares.es & Gijón & ayto-gijon.es & Puerto Sta María & elpuertosm.es \\
\hline Alcobendas & alcobendas.org & Girona & ajuntament.gi & Reus & reus.net \\
\hline Alcorcón & ayto-alcorcon.es & Granada & granada.org & Sabadell & sabadell.net \\
\hline Algeciras & ayto-algeciras.es & Guadalajara & guadalajara.es & Salamanca & aytosalamanca.es \\
\hline Almería & aytoalmeria.es & Huelva & ayuntamientohuelva.es & San Fernando & aytosanfernando.org \\
\hline Ávila & ayuntavila.com & Huesca & ayuntamientohuesca.es & San Sebastián & donostia.org \\
\hline Avilés & ayto-aviles.es & Jaén & aytojaen.es & Sant Boi & stboi.es \\
\hline Badajoz & aytobadajoz.es & Jerez & webjerez.com & Sta C Gramenet & grame.net \\
\hline Badalona & aj-badalona.es & Leganés & leganes.org & Sta Cruz Tenerife & sctfe.es \\
\hline Baracaldo & barakaldo.org & León & aytoleon.com & Santander & ayto-santander.es \\
\hline Bilbao & bilbao.net & Logroño & logro-o.org & Segovia & segovia.es \\
\hline Burgos & aytoburgos.es & Lorca & ayuntalorca.es & Sevilla & sevilla.org \\
\hline Cáceres & ayto-caceres.es & Lugo & concellodelugo.org & Soria & ayto-soria.org \\
\hline Cádiz & cadizayto.es & Madrid & munimadrid.es & Talavera & talavera.org \\
\hline Cartagena & ayto-cartagena.com & Málaga & ayto-malaga.es & Tarragona & ajtarragona.es \\
\hline Castellón & ayuncas.es & Marbella & marbella.es & Telde & ayuntamientodetelde.org \\
\hline Ceuta & ciceuta.es & Mataró & mataro.org & Terrassa & terrassa.org \\
\hline Ciudad Real & ayto-ciudadreal.es & Melilla & camelilla.es & Teruel & teruel.net \\
\hline Córdoba & ayuncordoba.es & Móstoles & ayto-mostoles.es & Toledo & ayto-toledo.org \\
\hline Cornellá & cornellaweb.com & Murcia & ayto-murcia.es & Torrejón de Ardoz & ayto-torrejon.es \\
\hline Coruña & aytolacoruna.es & Ourense & ourense.es & Torrevieja & ayto.torrevieja.infoville.net \\
\hline Coslada & ayto-coslada.es & Oviedo & ayto-oviedo.es & Valencia & valencia.es \\
\hline Dos Hermanas & doshermanas.es & Palma de Mallorca & a-palma.es & Vigo & vigo.org \\
\hline Elche & ayto-elche.es & Palmas G Canaria & laspalmasgc.es & Vitoria-Gasteiz & vitoria-gasteiz.org \\
\hline Ferrol & ferrol-concello.es & Pamplona & pamplona.net & Zamora & ayto-zamora.org \\
\hline Fuenlabrada & ayto-fuenlabrada.es & Parla & ayuntamientoparla.es & Zaragoza & ayto-zaragoza.es \\
\hline Getafe & ayto-getafe.org & Pontevedra & concellopontevedra.es & & \\
\hline
\end{tabular}

Table 1. List of councils analysed and their websites 


\begin{tabular}{l|c}
\hline \multicolumn{1}{c|}{ Financial information disclosed via the Internet } & $N(\%)$ \\
\hline Discloses financial information regarding budget or annual accounts (e-DISCL) & $49(53.26 \%)$ \\
\hline 1. Individual budget of the council (BUDG1) & $47(51,08 \%)$ \\
\hline 2. Consolidated budget of the council (BUDG2) & $33(35.86 \%)$ \\
\hline 3. Budget of dependent entities (BUDG3) & $36(39.13 \%)$ \\
\hline 4. Budget disaggregated by economic, functional or organic classification (BUDG4) & $26(28.26 \%)$ \\
\hline 5. Budget information regarding investment, borrowing or revenue and expenditure (BUDG5) & $12(13.04 \%)$ \\
\hline 6. Individual annual accounts (ACC1) & $1(1.08 \%)$ \\
\hline 7. Consolidated annual accounts (ACC2) & $1(1.08 \%)$ \\
\hline 8. Annual accounts of dependent entities (ACC3) & $0(0 \%)$ \\
\hline 9. Audit report (AUDIT) & $2(2.17 \%)$ \\
\hline
\end{tabular}

Table 2. Financial variables and number (percentage) of councils which disclose such information. 


\begin{tabular}{|c|c|c|}
\hline & Variable & Definition \\
\hline \multirow[t]{2}{*}{ H1. Size } & POPUL & Number of inhabitants of the municipality \\
\hline & REVEN & Budget revenue \\
\hline H2. Listed & BOND & Issue debt. Dichotomic 0-1 \\
\hline \multirow{5}{*}{$\begin{array}{r}\text { H3. Financial } \\
\text { features }\end{array}$} & INV & Investment per inhabitant \\
\hline & TAX & Tax burden per inhabitant \\
\hline & SELF & Tax revenue / Operating revenue \\
\hline & FINANC & Financial expenses / Total expenses \\
\hline & OPERAT & Operating expenses / Total expenses \\
\hline \multirow[t]{3}{*}{ H4. Political } & COMP & Political competition. Candidates/councillors ratio \\
\hline & COAL & Coalition government. \\
\hline & POLOR & Political orientation of the government in power \\
\hline \multirow[t]{3}{*}{ H5. e-government } & eDEM & Number of e-democracy actions implemented \\
\hline & eCONT & Contents offered on the municipal website \\
\hline & eSERV & Number of services offered via the Internet \\
\hline \multirow{2}{*}{$\begin{array}{l}\text { H6. Internet } \\
\text { visibility }\end{array}$} & LINKS & Link popularity. Number of incoming links according to MSN \\
\hline & POSTS & Number of posts on blogs according to Technorati \\
\hline $\begin{array}{r}\text { H7. Income level } \\
\text { of citizens }\end{array}$ & WEALTH & Disposable family income per inhabitant of the municipality- \\
\hline \multirow{3}{*}{$\begin{array}{l}\text { H8. Socio- } \\
\text { political, } \\
\text { education }\end{array}$} & VOTE & Voter turnout \\
\hline & ASSOC & Number of community associations, divided by the number of inhabitants \\
\hline & EDU & Average years of school \\
\hline
\end{tabular}

Table 3. Variables employed for the hypothesis testing and their definition 


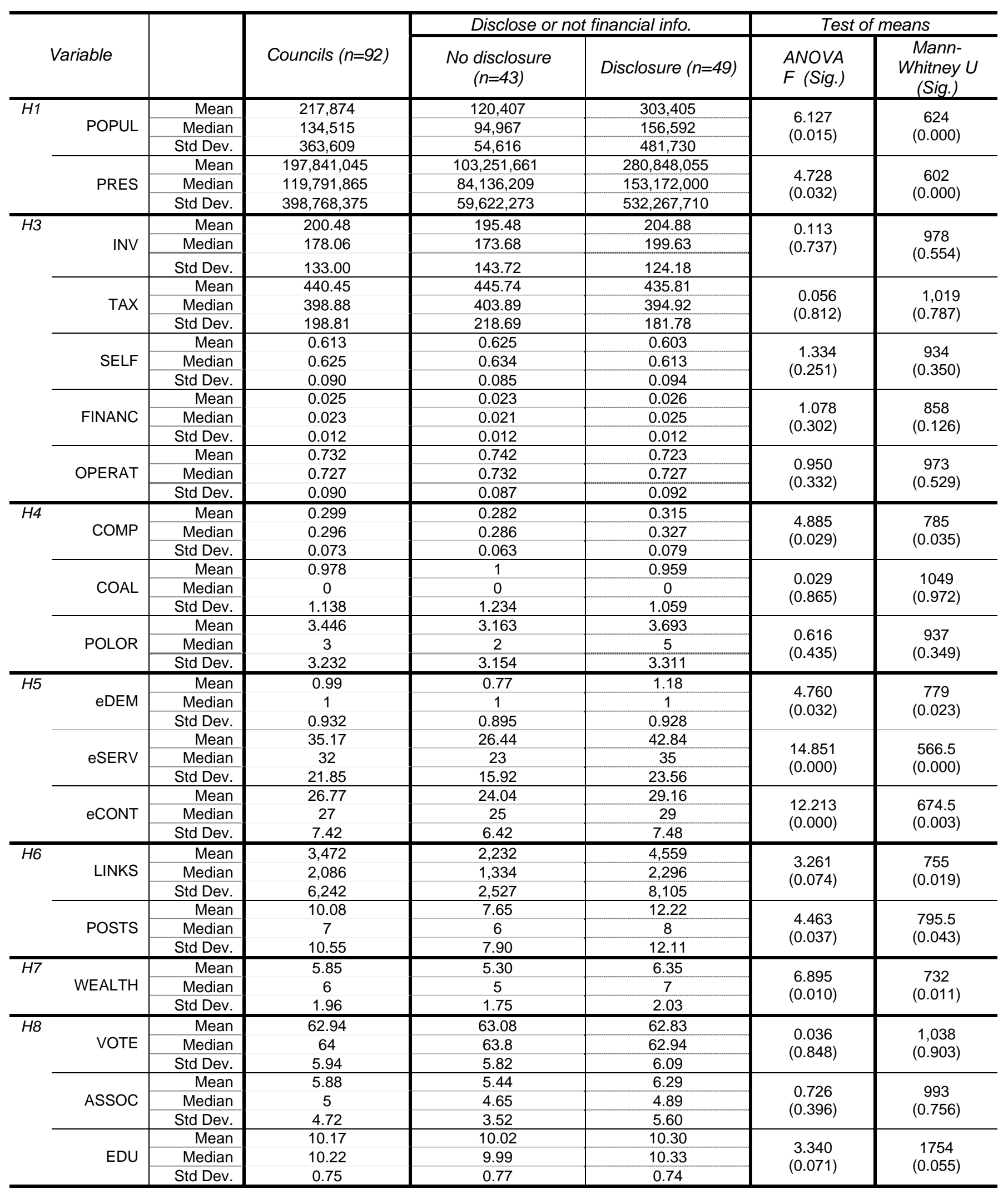

Table 4. Study of Internet financial disclosure by councils. Continuous variables. 


\begin{tabular}{rr|c|c|c|c}
\cline { 2 - 5 } & $\begin{array}{c}\text { No } \\
\text { disclosure }\end{array}$ & Disclosure & Total & Pearson Chi-Square \\
\hline H2 BOND & 1 & 11 & 12 & $8.177(0.004)$ \\
& 42 & 38 & 80 & \\
Non-BOND & 43 & 49 & 92 & \\
Total & 43 &
\end{tabular}

Table 5. Study of Internet financial disclosure by councils. Categorical variable. 


\begin{tabular}{|c|c|c|c|c|c|c|c|c|c|c|c|c|c|c|c|c|c|c|c|}
\hline & $\begin{array}{l}\vec{D} \\
\text { on } \\
0\end{array}$ & $\begin{array}{l}\mathscr{w} \\
\frac{\tilde{\alpha}}{\alpha}\end{array}$ & $\gtreqless$ & $\underset{1}{\stackrel{x}{1}}$ & 岀 & $\underset{\frac{1}{L}}{\stackrel{U}{L}}$ & $\begin{array}{l}\text { 衣 } \\
\text { 岀 } \\
0 \\
0\end{array}$ & $\sum_{0}^{0}$ & 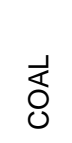 & 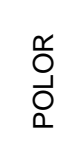 & $\underset{\text { 岃 }}{\sum_{0}}$ & 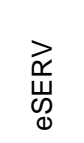 & 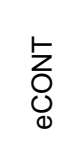 & $\begin{array}{l}\mathcal{N} \\
\underline{\underline{z}} \\
\underline{\exists}\end{array}$ & $\begin{array}{l}0 \\
\omega \\
0 \\
\square\end{array}$ & $\frac{I}{\stackrel{I}{\leftrightarrows}}$ & 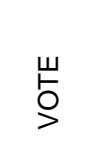 & $\begin{array}{l}0 \\
\text { O } \\
\text { O } \\
\text { \& }\end{array}$ & 금 \\
\hline \multirow{2}{*}{ POPUL } & 1 & $.99 * \star$ & -.02 & -.05 & $-.22^{\star}$ & .16 & .02 & $.22^{\star}$ & -.06 & -.08 & .04 & $.47^{\star \star}$ & $.40^{\star *}$ & $.56^{\star \star}$ & .12 & .19 & .05 & $.53^{\star \star}$ & .12 \\
\hline & 1 & $.84^{\star *}$ & $-.21^{*}$ & $-.23^{*}$ & $-.37^{\star *}$ & $.24^{*}$ & $.22^{*}$ & $.32^{\star *}$ & -.04 & -.10 & .01 & $.62^{\star \star}$ & $.47^{\star *}$ & $.50 \star *$ & $.42^{\star *}$ & .01 & -.13 & .18 & .02 \\
\hline \multirow[b]{2}{*}{ PRES } & & 1 & .09 & .05 & -.19 & .13 & -.05 & $.22^{\star}$ & -.03 & -.07 & .03 & $.42^{\star *}$ & $.37^{\star *}$ & $.59 \star *$ & .09 & $.24^{*}$ & .07 & $.52^{\star \star}$ & .13 \\
\hline & & 1 & .18 & .13 & $-.30^{\star *}$ & .12 & -.01 & $.43^{\star *}$ & -.03 & -.15 & .08 & $.53^{\star *}$ & $.40^{\star *}$ & $.53^{\star \star}$ & $.42^{\star \star}$ & .11 & -.01 & $.22^{*}$ & .13 \\
\hline \multirow{2}{*}{ INV } & & & 1 & $.60^{\star \star}$ & .06 & $-.42^{\star \star}$ & $-.75^{\star \star}$ & .19 & .05 & -.17 & .02 & -.20 & -.16 & .04 & -.07 & $.27^{\star *}$ & $.23^{\star}$ & .07 & .15 \\
\hline & & & 1 & $.39 \star \star$ & .00 & $-.41^{\star \star}$ & $-.85^{\star \star}$ & .14 & .05 & -.11 & .00 & -.17 & -.11 & -.07 & -.09 & $.36^{* *}$ & $.33^{\star \star}$ & .08 & $.32^{\star \star}$ \\
\hline \multirow{2}{*}{ TAX } & & & & 1 & $.47^{\star \star}$ & -.07 & -.12 & .15 & -.07 & -.08 & .08 & -.13 & -.10 & .09 & -.02 & .10 & -.01 & .08 & -.01 \\
\hline & & & & 1 & $.57^{\star \star}$ & .03 & -.17 & .07 & -.02 & -.04 & .11 & -.08 & .01 & .10 & .03 & $.23^{*}$ & .15 & .17 & $.31^{\star *}$ \\
\hline \multirow{2}{*}{ SELF } & & & & & 1 & .07 & -.04 & -.10 & -.18 & .04 & .06 & $-.23^{*}$ & -.10 & -.19 & $-.27^{\star \star}$ & -.05 & -.02 & .16 & .01 \\
\hline & & & & & 1 & .02 & -.05 & -.06 & -.20 & .00 & .10 & $-.21^{*}$ & -.10 & -.03 & -.16 & -.01 & .00 & .16 & .07 \\
\hline \multirow{2}{*}{ FINANC } & & & & & & 1 & $.45^{\star *}$ & .09 & .10 & .15 & -.03 & .16 & .05 & .15 & -.13 & -.09 & -.14 & .03 & -.11 \\
\hline & & & & & & 1 & $.38^{\star *}$ & .09 & .10 & .16 & .04 & $.21^{\star}$ & .05 & .15 & -.03 & -.10 & -.17 & .08 & -.13 \\
\hline \multirow{2}{*}{ OPERAT } & & & & & & & 1 & -.08 & -.06 & -.01 & -.04 & .16 & .07 & -.02 & .13 & $-.22^{*}$ & $-.29^{\star \star}$ & -.07 & $-.24^{*}$ \\
\hline & & & & & & & 1 & -.05 & -.08 & -.07 & .00 & .16 & .08 & .14 & .17 & $-.26^{*}$ & $-.33^{\star \star}$ & -.10 & $-.31^{* *}$ \\
\hline \multirow{2}{*}{ COMP } & & & & & & & & 1 & .13 & -.09 & .05 & .20 & $.21^{*}$ & $.26^{\star}$ & $.21^{*}$ & $.28^{\star *}$ & .03 & .19 & .17 \\
\hline & & & & & & & & 1 & .16 & -.03 & .08 & $.24^{*}$ & .14 & $.27^{\star \star}$ & $.22^{*}$ & $.28^{\star *}$ & .01 & .17 & .17 \\
\hline \multirow{2}{*}{ COAL } & & & & & & & & & 1 & $.51^{\star *}$ & .11 & .18 & .10 & .13 & $.27^{\star *}$ & $.28^{* *}$ & -.01 & $-.29 \star *$ & -.04 \\
\hline & & & & & & & & & 1 & $.57^{\star *}$ & .09 & .18 & .13 & -.02 & $.25^{\star}$ & $.26^{*}$ & -.03 & $-.33^{\star \star}$ & -.06 \\
\hline \multirow{2}{*}{ POLOR } & & & & & & & & & & 1 & .03 & .16 & .11 & .09 & .11 & .08 & -.16 & $-.24^{\star}$ & $-.22^{*}$ \\
\hline & & & & & & & & & & 1 & .01 & .12 & .06 & -.04 & .11 & .10 & -.16 & $-.21^{*}$ & $-.21^{*}$ \\
\hline \multirow{2}{*}{ eDEM } & & & & & & & & & & & 1 & $.22^{\star}$ & $.30^{\star *}$ & .07 & .20 & .02 & .13 & .17 & .13 \\
\hline & & & & & & & & & & & 1 & $.23^{\star}$ & $.27^{\star *}$ & $.24^{*}$ & $.34^{\star *}$ & .05 & .12 & $.21^{*}$ & .16 \\
\hline \multirow{2}{*}{ eSERV } & & & & & & & & & & & & 1 & $.69^{\star *}$ & $.40 * *$ & $.31 * *$ & .19 & -.09 & .11 & .03 \\
\hline & & & & & & & & & & & & 1 & $.67^{\star *}$ & $.47^{\star *}$ & $.42^{\star *}$ & $.22^{*}$ & -.13 & -.04 & .07 \\
\hline \multirow{2}{*}{ eCONT } & & & & & & & & & & & & & 1 & $.34^{\star *}$ & $.32^{\star \star}$ & $.35^{\star *}$ & .15 & $.24^{*}$ & $.21^{*}$ \\
\hline & & & & & & & & & & & & & 1 & $.40^{\star *}$ & $.36^{\star *}$ & $.36^{\star *}$ & .16 & .08 & $.22^{*}$ \\
\hline \multirow{2}{*}{ LINKS } & & & & & & & & & & & & & & 1 & $.28^{\star *}$ & .29 ** & -.05 & .02 & .11 \\
\hline & & & & & & & & & & & & & & 1 & $.50^{\star *}$ & .18 & -.13 & .08 & .12 \\
\hline \multirow{2}{*}{ POSTS } & & & & & & & & & & & & & & & 1 & .19 & -.05 & -.02 & .16 \\
\hline & & & & & & & & & & & & & & & 1 & .10 & -.11 & -.02 & .10 \\
\hline \multirow{2}{*}{ WEALTH } & & & & & & & & & & & & & & & & 1 & $.41^{\star *}$ & .14 & $.44^{\star \star}$ \\
\hline & & & & & & & & & & & & & & & & 1 & $.39^{\star \star}$ & -.02 & $.41^{\star \star}$ \\
\hline \multirow{2}{*}{ VOTE } & & & & & & & & & & & & & & & & & 1 & $.39 \star *$ & $.58^{\star *}$ \\
\hline & & & & & & & & & & & & & & & & & 1 & $.44^{\star *}$ & $.59^{* *}$ \\
\hline \multirow{2}{*}{ ASSOC } & & & & & & & & & & & & & & & & & & 1 & $.46^{* *}$ \\
\hline & & & & & & & & & & & & & & & & & & 1 & $.49^{\star *}$ \\
\hline EDU & & & & & & & & & & & & & & & & & & & $\begin{array}{l}1 \\
1\end{array}$ \\
\hline
\end{tabular}

Table 6. Correlation coefficients. First line, Pearson's. Second line, Spearman's.

** significant at the 0.01 level

* significant at the 0.05 level 


\begin{tabular}{ccccc} 
& Expected sign & Coefficient & Wald & Significance \\
\hline Constant & & -19.417 & 12.964 & 0.000 \\
\hline LnPOPUL & + & 1.441 & 10.861 & 0.001 \\
\hline WEALTH & + & 0.340 & 6.494 & 0.011 \\
\hline EDEM & + & 0.555 & 4.314 & 0.038 \\
\hline
\end{tabular}

Note: $\mathrm{N}=92$ cases; -2 Log likelihood $=101.200 ;$ Nagelkerke $R^{2}=0.328$; Chi square $=$ 25.947; significance of Chi square $=0.000$

Correctly predicted percentage. NonREV=67.4 REV=77.6; overall=72.8 information

eDISCL = Dummy variable takes value of 1 if the council discloses financial

LnPOPUL = Number of inhabitants logarithm

WEALTH = Per capita income in the municipality

eDEM = Number of e-democracy actions implemented

Table 7. Multivariate Logistic Regression 


\section{DOCUMENTOS DE TRABAJO}

Facultad de Ciencias Económicas y Empresariales

Universidad de Zaragoza

2002-01: "Evolution of Spanish Urban Structure During the Twentieth Century". Luis Lanaspa, Fernando Pueyo y Fernando Sanz. Department of Economic Analysis, University of Zaragoza.

2002-02: “Una Nueva Perspectiva en la Medición del Capital Humano”. Gregorio Giménez y Blanca Simón. Departamento de Estructura, Historia Económica y Economía Pública, Universidad de Zaragoza.

2002-03: "A Practical Evaluation of Employee Productivity Using a Professional Data Base”. Raquel Ortega. Department of Business, University of Zaragoza.

2002-04: "La Información Financiera de las Entidades No Lucrativas: Una Perspectiva Internacional”. Isabel Brusca y Caridad Martí. Departamento de Contabilidad y Finanzas, Universidad de Zaragoza.

2003-01: "Las Opciones Reales y su Influencia en la Valoración de Empresas". Manuel Espitia y Gema Pastor. Departamento de Economía y Dirección de Empresas, Universidad de Zaragoza.

2003-02: "The Valuation of Earnings Components by the Capital Markets. An International Comparison”. Susana Callao, Beatriz Cuellar, José Ignacio Jarne and José Antonio Laínez. Department of Accounting and Finance, University of Zaragoza.

2003-03: "Selection of the Informative Base in ARMA-GARCH Models". Laura Muñoz, Pilar Olave and Manuel Salvador. Department of Statistics Methods, University of Zaragoza.

2003-04: "Structural Change and Productive Blocks in the Spanish Economy: An Imput-Output Analysis for 1980-1994”. Julio Sánchez Chóliz and Rosa Duarte. Department of Economic Analysis, University of Zaragoza.

2003-05: "Automatic Monitoring and Intervention in Linear Gaussian State-Space Models: A Bayesian Approach”. Manuel Salvador and Pilar Gargallo. Department of Statistics Methods, University of Zaragoza.

2003-06: "An Application of the Data Envelopment Analysis Methodology in the Performance Assessment of the Zaragoza University Departments”. Emilio Martín. Department of Accounting and Finance, University of Zaragoza.

2003-07: "Harmonisation at the European Union: a difficult but needed task". Ana Yetano Sánchez. Department of Accounting and Finance, University of Zaragoza. 
2003-08: "The investment activity of spanish firms with tangible and intangible assets”. Manuel Espitia and Gema Pastor. Department of Business, University of Zaragoza.

2004-01: "Persistencia en la performance de los fondos de inversión españoles de renta variable nacional (1994-2002)”. Luis Ferruz y María S. Vargas. Departamento de Contabilidad y Finanzas, Universidad de Zaragoza.

2004-02: "Calidad institucional y factores político-culturales: un panorama internacional por niveles de renta”. José Aixalá, Gema Fabro y Blanca Simón. Departamento de Estructura, Historia Económica y Economía Pública, Universidad de Zaragoza.

2004-03: “La utilización de las nuevas tecnologías en la contratación pública”. José Mª Gimeno Feliú. Departamento de Derecho Público, Universidad de Zaragoza.

2004-04: "Valoración económica y financiera de los trasvases previstos en el Plan Hidrológico Nacional español”. Pedro Arrojo Agudo. Departamento de Análisis Económico, Universidad de Zaragoza. Laura Sánchez Gallardo. Fundación Nueva Cultura del Agua.

2004-05: "Impacto de las tecnologías de la información en la productividad de las empresas españolas”. Carmen Galve Gorriz y Ana Gargallo Castel. Departamento de Economía y Dirección de Empresas. Universidad de Zaragoza.

2004-06: "National and International Income Dispersión and Aggregate Expenditures”. Carmen Fillat. Department of Applied Economics and Economic History, University of Zaragoza. Joseph Francois. Tinbergen Institute Rotterdam and Center for Economic Policy Resarch-CEPR.

2004-07: “Targeted Advertising with Vertically Differentiated Products”. Lola Esteban and José M. Hernández. Department of Economic Analysis. University of Zaragoza.

2004-08: "Returns to education and to experience within the EU: are there differences between wage earners and the self-employed?”. Inmaculada García Mainar. Department of Economic Analysis. University of Zaragoza. Víctor M. Montuenga Gómez. Department of Business. University of La Rioja

2005-01: "E-government and the transformation of public administrations in EU countries: Beyond NPM or just a second wave of reforms?”. Lourdes Torres, Vicente Pina and Sonia Royo. Department of Accounting and Finance.University of Zaragoza

2005-02: "Externalidades tecnológicas internacionales y productividad de la manufactura: un análisis sectorial”. Carmen López Pueyo, Jaime Sanau y Sara Barcenilla. Departamento de Economía Aplicada. Universidad de Zaragoza.

2005-03: "Detecting Determinism Using Recurrence Quantification Analysis: Three Test Procedures”. María Teresa Aparicio, Eduardo Fernández Pozo and Dulce Saura. Department of Economic Analysis. University of Zaragoza. 
2005-04: "Evaluating Organizational Design Through Efficiency Values: An Application To The Spanish First Division Soccer Teams”. Manuel Espitia Escuer and Lucía Isabel García Cebrián. Department of Business. University of Zaragoza.

2005-05: "From Locational Fundamentals to Increasing Returns: The Spatial Concentration of Population in Spain, 1787-2000". María Isabel Ayuda. Department of Economic Analysis. University of Zaragoza. Fernando Collantes and Vicente Pinilla. Department of Applied Economics and Economic History. University of Zaragoza.

2005-06: "Model selection strategies in a spatial context". Jesús Mur and Ana Angulo. Department of Economic Analysis. University of Zaragoza.

2005-07: “Conciertos educativos y selección académica y social del alumnado". María Jesús Mancebón Torrubia. Departamento de Estructura e Historia Económica y Economía Pública. Universidad de Zaragoza. Domingo Pérez Ximénez de Embún. Departamento de Análisis Económico. Universidad de Zaragoza.

2005-08: "Product differentiation in a mixed duopoly". Agustín Gil. Department of Economic Analysis. University of Zaragoza.

2005-09: "Migration dynamics, growth and convergence". Gemma Larramona and Marcos Sanso. Department of Economic Analysis. University of Zaragoza.

2005-10: "Endogenous longevity, biological deterioration and economic growth". Marcos Sanso and Rosa María Aísa. Department of Economic Analysis. University of Zaragoza.

2006-01: "Good or bad? - The influence of FDI on output growth. An industry-level analysis“. Carmen Fillat Castejón. Department of Applied Economics and Economic History. University of Zaragoza. Julia Woerz. The Vienna Institute for International Economic Studies and Tinbergen Institute, Erasmus University Rotterdam.

2006-02: "Performance and capital structure of privatized firms in the European Union”. Patricia Bachiller y M $\mathbf{M}^{\mathrm{a}}$ José Arcas. Departamento de Contabilidad y Finanzas. Universidad de Zaragoza.

2006-03: "Factors explaining the rating of Microfinance Institutions". Begoña Gutiérrez Nieto and Carlos Serrano Cinca. Department of Accounting and Finance. University of Saragossa, Spain.

2006-04: “Libertad económica y convergencia en argentina: 1875-2000”. Isabel Sanz Villarroya. Departamento de Estructura, Historia Económica y Economía Pública. Universidad de Zaragoza. Leandro Prados de la Escosura. Departamento de $\mathrm{H}^{\mathrm{a}} \mathrm{e}$ Instituciones Ec. Universidad Carlos III de Madrid.

2006-05: "How Satisfied are Spouses with their Leisure Time? Evidence from Europe*”. Inmaculada García, José Alberto Molina y María Navarro. University of Zaragoza. 
2006-06: "Una estimación macroeconómica de los determinantes salariales en España (1980-2000)”. José Aixalá Pastó y Carmen Pelet Redón. Departamento de Estructura, Historia Económica y Economía Pública. Universidad de Zaragoza.

2006-07: "Causes of World Trade Growth in Agricultural and Food Products, 1951 2000". Raúl Serrano and Vicente Pinilla. Department of Applied Economics and Economic History, University of Zaragoza, Gran Via 4, 50005 Zaragoza (Spain).

2006-08: "Prioritisation of patients on waiting lists: a community workshop approach”. Angelina Lázaro Alquézar. Facultad de Derecho, Facultad de Económicas. University of Zaragoza. Zaragoza, Spain. Begoña Álvarez-Farizo. C.I.T.A.- Unidad de Economía. Zaragoza, Spain

2007-01: "Deteminantes del comportamiento variado del consumidor en el escenario de Compra”. Carmén Berné Manero y Noemí Martínez Caraballo. Departamento de Economía y Dirección de Empresas. Universidad de Zaragoza.

2007-02: “Alternative measures for trade restrictiveness. A gravity approach". Carmen Fillat \& Eva Pardos. University of Zaragoza.

2007-03: "Entrepreneurship, Management Services and Economic Growth”. Vicente Salas Fumás \& J. Javier Sánchez Asín. Departamento de Economía y Dirección de Empresas. University of Zaragoza.

2007-04: "Equality versus Equity based pay systems and their effects on rational altruism motivation in teams: Wicked masked altruism”. Javier García Bernal \& Marisa Ramírez Alerón. University of Zaragoza.

2007-05: "Macroeconomic outcomes and the relative position of Argentina's Economy: 1875-2000”. Isabel Sanz Villarroya. University of Zaragoza.

2008-01: "Vertical product differentiation with subcontracting”. Joaquín Andaluz Funcia. University of Zaragoza.

2008-02: "The motherwood wage penalty in a mediterranean country: The case of Spain” Jose Alberto Molina Chueca \& Victor Manuel Montuenga Gómez. University of Zaragoza.

2008-03: "Factors influencing e-disclosure in local public administrations". Carlos Serrano Cinca, Mar Rueda Tomás \& Pilar Portillo Tarragona. Departamento de Contabilidad y Finanzas. Universidad de Zaragoza. 